\title{
Organosomatic indices and histopathological response of Clarias gariepinus fed Roselle (Hibiscus sabdariffa) meal diets
}

\author{
Adewole, A. M.
}

Department of Animal and Environmental Biology, Adekunle Ajasin University, Akungba Akoko, Ondo State, Nigeria

Corresponding author: adewole.adeyemo@aaua.edu.ng / adewoleyemo68@gmail.com; 07037354046/08116352281

\section{Abstract}

In the study, the effects of different dosages of Hibiscus sabdariffa meal diets on the organosomatic indices and histopathology of organs $(n=20)$ of juvenile Clarias gariepinus was evaluated. The fish with initial mean weight and length: $10.94 \pm 0.02 \mathrm{~g}$ and $10.28 \pm 0.04 \mathrm{~cm}$ were stocked in triplicates per treatments. The fishes were fed twice daily at $5 \%$ body weight, for 12 weeks. Six isonitrogenous diets containing 40\% crude protein were formulated and coded as Hibiscus sabdariffa meall (SM1Control), Hibiscus sabdariffa meal 2 (HSM2), Hibiscus sabdariffa meal 3 (HSM3), Hibiscus sbadariffa meal 4 (HSM4), Hibiscus sbadariffa meal 5 (HSM5) and Hibiscus sabdariffa meal 6 (HSM6), respectively. Organosomatic indices such as cardiosomatic index (CSI), Hepatosomatic index (HIS), Renalsomatic index (RSI), Visceralsomatic index (VSI), Cerebrosomatic index (CBSI) and Fat deposit index (FDI) of the fish were measured using standard methods. Histopathological examinations of the organs were carried out following routine laboratory techniques. Data were analyzed using descriptive statistics and ANOVA at $\alpha 0.05$. The result revealed asignificant differences in all the orgaosomatic indices except VSI within the treatments and control. The histopathological examinations of the liver of C. gariepinus revealed a gradual changes from mild to moderate and severe diffuse hepatic vacuolar degenerations as the concentrations of $H$. sabdariffa meal diets increased. The intestine showed a mild stunted gastric villi in fish fed HSM4 diet which had the highest growth data not shown. The study revealed that the consumption of unnecessarily high dose of $H$. sabdariffa for a long period should be taken with caution, despite the improved growth performance observed. Further studies on the effect of processing cum detoxification of the Roselle in fish as an animal model should be undertaken.

Keywords: somatic indices, organs, aquaculture, phytogenic, additive, Fish nutrition, health management

\section{Introduction}

The consumption of botanicals (phytogenic) as complementary/alternative medicine has been encouraged because they are relatively cheap and their significant contribution to the improvement of both human and animal health in term of cure and the prevention of various human/animal disorders, in addition to the less frequent side effects reported when compared to modern medicine or synthetic drugs (Hu et. al., 2003). Most of the phytogenic used can be regarded as spices.
Spices are being used as food additives since ancient times mostly for their organoleptic attributes. It is now understood that spices also exhibit several beneficial nutritional/ physiological effects in addition to enhancing taste and flavour of food (Ezekwesili et al, 2004). The digestive stimulant action of spices has been well recognized for a long time, and a few of them find pharmacological application against digestive disorders (Atal and Kapur, 1987). In addition to the various nutrients possessed by these spices, arrays of 


\section{Organosomatic indices and histopathological response of Clarias gariepinus}

phytochemicals have also been identified in their different parts used for food items, those that have been identified include saponins, tannins, anthocyanin's, cyanogenic glycosides, flavones, and polyphenols (Wang et al, 2000) from H.sabdariffa. Furthermore, phytogenic feed additives are used in animal feeds to improve performance through amelioration of feed properties, promotion of production performance and improving the quality of animal origin food/feed (Aletor and Osho, 2009). The use of $H$. sabdariffa as dietary additive and growth promotants in $C$. gariepinus have been reported (Adewole, 2014). However, the present studies focuses on reporting the effects of feeding different concentrations of $H$. sabdariffa on the organosomatic indices and histopathological conditions of the organs of C. gariepinus.

\section{Materials and methods \\ Studyarea}

The study was carried out at the Department of Aquaculture and Fisheries Management's Teaching and Research Laboratory, University of Ibadan, Ibadan, Oyo State. Nigeria.

Collection, dosages, preparation, processing of $H$. sabdariffa for formulation and preparation of diets, stocking and feeding

The dried flower (calyx) of $H$. sabdariffa was purchased at Bodija Market, Ibadan Oyo State. The preparation, processing and calculation of the dosages ranged from $(0.0375$ to $0.60 \mathrm{~g} / 100 \mathrm{~g})$ for Roselle calyx were done as reported by Adewole (2014). The diets were later dried, labeled and coded: Hibiscus sabdariffa meall (HSM1) - Hibiscus sabdariffa meal 6 (HSM6) as reported by Adewole (2014). Twenty juveniles mean weight and length of $10.94 \pm 0.02 \mathrm{~g}$ and $10.28 \pm 0.04 \mathrm{~cm}$ respectively were stocked and fed twice daily at $5 \%$ body weight in triplicates for 12 weeks in a completely randomized design as reported by Adewole (2014).

\section{Collections of organs and} histopathological analysis

The fish $(\mathrm{n}=5)$ were dissected to remove the organs after the feeding trial from each treatments. The organs were weighed separately and recorded for somatic indices as adapted from Dogan and Can (2011). Each organ was dehydrated in Periodic Acid Schiff's reagent (PAS) following the method of Hughes and Perry (1976). They were cleaned, impregnated with wax and sectioned with a microtone ( $5 \mathrm{~m}$ thickness). Slides were prepared at the Department of Veterinary Pathology, University of Ibadan, Nigeria. Histopathological examination was carried out to investigate possible abnormalities in the organs and the magnification was taken at $100 \mathrm{X}$ according to Roberts (1978).

\section{Results and discussion}

The Cardiosomatic indices (CSI) of the fish fed the experimental diet ranged from $0.11 \pm$ $0.01 \%-0.21 \pm 0.02 \%$. The highest CSI value of $0.21 \pm 0.02 \%$ was from the fish fed control diet, followed closely by $0.15 \pm$ $0.01 \%$ that was jointly from fish fed HSM 4 and HSM6 diets respectively, while the lowest value for CSI was from fish fed HSM5 diet (Table 1). The HSI values varied from $0.84 \pm 0.18 \%$ to $1.66 \pm 9 \%$. The highest value was from the fish fed HSM2 diet, while the lowest was from the fish fed HSM3 diet. The fish fed HSM2 diet had HIS significantly higher $(\mathrm{P}<0.05)$ than fish fed HSM1, HSM3 and HSM5 diets, but not significantly different from fish fed HSM4 and HSM6 diets, respectively (Table 1). The highest value $(0.04 \pm 0.01 \%)$ for RSI was from the fish fed HSM4 diet and the lowest value $(0.21 \pm 0.02 \%)$ was from the fish fed HSM4 diet. The fish fed the HSM3, HSM4 and HSM6 diets had significantly 


\section{Adewole}

higher $(\mathrm{p}<0.05)$ RSI than fish fed HSM1,HSM2 and HSM5 diets respectively (Table 1).The VSI ranged from to $2.92 \pm$ $0.05 \%$ to $2.32 \pm 0.30 \%$. The highest value was from the fish fed HSM6 diet, followed closely by $2.85 \pm 0.09 \%$ from the fish fed HSM3 diet, while the lowest was from fish fed the control diet. The fish fed the control diet was insignificantly lower $(p>0.05)$ than the others (Table 1). The histopathological results showed that there were no visible lesion found in the heart, brain, kidney, gill of $C$. gariepinus fed graded levels of HSM diets (Table 2), but there were varied degree of histopathological alterations in the structural architecture of the liver (Platela and $1 \mathrm{~b}$ ) and the intestine (Plate 2a and 2b) of fish fed the $H$. sabdariffa meal diets.

Table 1: Organosomatic indices of Clarias gariepinus fed Hibiscus sabdariffa meal diets for 84 days in plastic tanks

Values with different superscripts in each row are significantly different $(P<0.05)$.

\begin{tabular}{|c|c|c|c|c|c|c|}
\hline \multicolumn{7}{|c|}{ Treatments fed to Clarias gariepinus for 84 days } \\
\hline Parameters & $\begin{array}{l}\text { Hibiscus } \\
\text { sabdariffa } \\
\text { meal1 } \\
\text { (HSM1) }\end{array}$ & $\begin{array}{l}\text { Hibiscus } \\
\text { sabdariffa } \\
\text { meal2 } \\
\text { (HSM2) }\end{array}$ & $\begin{array}{l}\text { Hibiscus } \\
\text { sabdariffa } \\
\text { meal3 } \\
\text { (HSM3) }\end{array}$ & $\begin{array}{l}\text { Hibiscus } \\
\text { sabdariffa } \\
\text { meal4 } \\
\text { (HSM4) }\end{array}$ & $\begin{array}{l}\text { Hibiscus } \\
\text { sabdariffa } \\
\text { meal5 } \\
\text { (HSM5) }\end{array}$ & $\begin{array}{l}\text { Hibiscus } \\
\text { sabdariffa } \\
\text { meal } 6 \\
\text { (HSM6) }\end{array}$ \\
\hline $\begin{array}{l}\text { Cardiosomatic } \\
\text { index (CSI) }\end{array}$ & $0.21 \pm 0.02^{\mathrm{a}}$ & $0.14 \pm 0.02^{\mathrm{b}}$ & $0.12 \pm 0.01^{\mathrm{b}}$ & $0.15 \pm 0.01^{\mathrm{b}}$ & $0.11 \pm 0.01^{\mathrm{b}}$ & $0.15 \pm 0.01^{\mathrm{b}}$ \\
\hline $\begin{array}{l}\text { Hepatosomatic } \\
\text { index (HIS) }\end{array}$ & $0.87 \pm 0.19^{\mathrm{b}}$ & $1.66 \pm 0.09^{\mathrm{a}}$ & $0.84 \pm 0.18^{\mathrm{b}}$ & $1.10 \pm 0.41^{\mathrm{ab}}$ & $0.87 \pm 0.11^{\mathrm{b}}$ & $1.22 \pm 0.08^{\mathrm{ab}}$ \\
\hline $\begin{array}{l}\text { Renosomatic } \\
\text { index (RSI) }\end{array}$ & $0.21 \pm 0.02^{\mathrm{c}}$ & $0.29 \pm 0.03^{\mathrm{bc}}$ & $0.34 \pm 0.02^{\mathrm{ab}}$ & $0.40 \pm 0.01^{\mathrm{a}}$ & $0.28 \pm 0.01^{\mathrm{bc}}$ & $0.37 \pm 0.05^{\mathrm{ab}}$ \\
\hline $\begin{array}{l}\text { Visceral } \\
\text { somatic index } \\
\text { (VSI) }\end{array}$ & $2.32 \pm 0.30$ & $2.61 \pm 0.31$ & $2.85 \pm 0.09$ & $2.56 \pm 0.23$ & $2.39 \pm 0.26$ & $2.92 \pm 0.05$ \\
\hline $\begin{array}{l}\text { Brain somatic } \\
\text { index (BSI) }\end{array}$ & $0.62 \pm 0.05^{\mathrm{a}}$ & $0.60 \pm 0.13^{\mathrm{ab}}$ & $0.45 \pm 0.08^{\mathrm{ab}}$ & $0.49 \pm 0.06^{\mathrm{ab}}$ & $0.35 \pm 0.03^{b}$ & $0.43 \pm 0.07^{\mathrm{ab}}$ \\
\hline $\begin{array}{l}\text { Fat deposit } \\
\text { index (FDI) }\end{array}$ & $2.73 \pm 0.23^{\mathrm{a}}$ & $2.39 \pm 0.21^{\mathrm{a}}$ & $0.90 \pm 0.17^{\mathrm{cd}}$ & $1.83 \pm 0.01^{\mathrm{b}}$ & $0.47 \pm 0.20^{\mathrm{d}}$ & $1.05 \pm 0.12^{\mathrm{c}}$ \\
\hline
\end{tabular}

Table 2. H istopathology of organs from Clarias gariepinus fed Hibiscus sabdariffa meal diets for 84 days in plastic tanks

\begin{tabular}{|c|c|c|c|c|c|c|}
\hline \multicolumn{7}{|c|}{ Treatments fed to Clarias gariepinus for 84 days } \\
\hline Organs & $\begin{array}{l}\text { Hibiscus } \\
\text { sabdariffa } \\
\text { meal1 } \\
\text { (HSM1) }\end{array}$ & $\begin{array}{l}\text { Hibiscus } \\
\text { sabdariffa } \\
\text { meal } 2 \\
\text { (HSM2) }\end{array}$ & $\begin{array}{l}\text { Hibiscus } \\
\text { sabdariffa } \\
\text { meal } 3 \\
\text { (HSM3) }\end{array}$ & $\begin{array}{l}\text { Hibiscus } \\
\text { sabdariffa } \\
\text { meal } 4 \\
\text { (HSM4) }\end{array}$ & $\begin{array}{l}\text { Hibiscus } \\
\text { sabdariffa } \\
\text { meal } 5 \\
\text { (HSM5) }\end{array}$ & $\begin{array}{l}\text { Hibiscus } \\
\text { sabdariffa } \\
\text { meal } 6 \\
\text { (HSM6) }\end{array}$ \\
\hline Brain & NVL & NVL & NVL & NVL & NVL & NVL \\
\hline Gill & NVL & NVL & NVL & NVL & NVL & NVL \\
\hline Heart & NVL & NVL & NVL & NVL & NVL & NVL \\
\hline Liver & NVL & $\begin{array}{l}\text { large loci of } \\
\text { vacuolation }\end{array}$ & $\begin{array}{l}\text { diffused } \\
\text { vacuolation } \\
\text { (moderate) }\end{array}$ & $\begin{array}{l}\text { mild } \\
\text { diffused } \\
\text { vacuolation }\end{array}$ & $\begin{array}{l}\text { severe } \\
\text { vacuolation } \\
\text { (diffused) }\end{array}$ & $\begin{array}{l}\text { severe } \\
\text { vacuolation }\end{array}$ \\
\hline $\begin{array}{l}\text { Intestine/ } \\
\text { Stomach }\end{array}$ & NVL & NVL & NVL & $\begin{array}{l}\text { slightly } \\
\text { shortened } \\
\text { gastric villi }\end{array}$ & short villi & short villi \\
\hline Kidney & NVL & NVL & NVL & NVL & NVL & NVL \\
\hline
\end{tabular}




\section{Organosomatic indices and histopathological response of Clarias gariepinus}

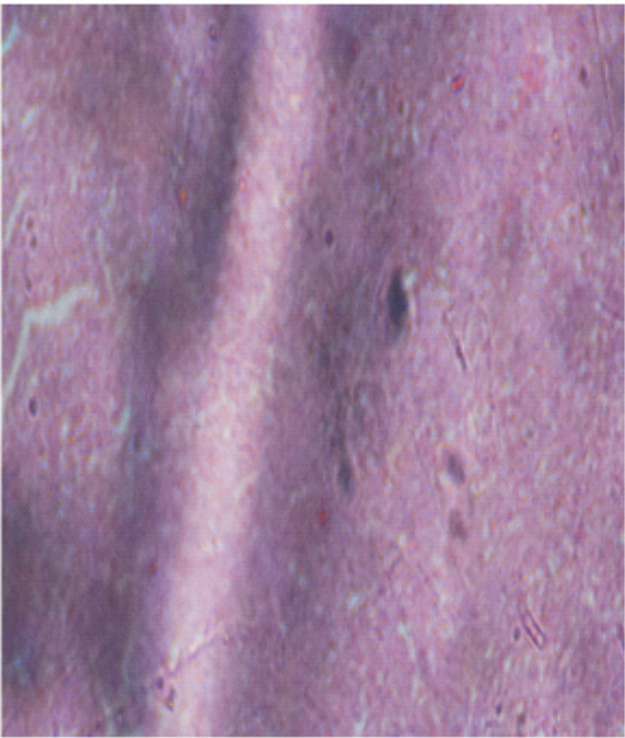

Plate:la.Photomicrograph of the transrerse section of the liser of Clarias gariepinus fed Hibiscis sabdariffa meal (HSMI) diet, showing wo visible lesion. H

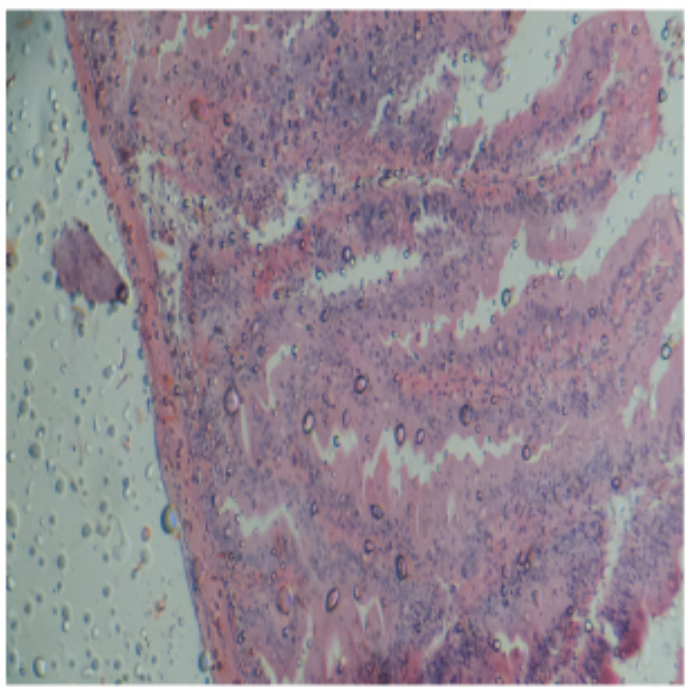

Plate2a:Photomicrograph of the transverse section of the stomach/intestine of Clarigs garieginas fed Vermomia anygdalima meal HSMIdiet showing no visible lesion.. H \& E. X

Organosomatic indices can be described as the ratios of organs to body weight; measured organs in relation to body mass can be directly linked to toxic effects of chemicals on target organ (Guillo and Hinton, 2008). It can also be used as indices of changes in nutritional and energy status (Maxwell and Dutta 2005). Stressors evoke

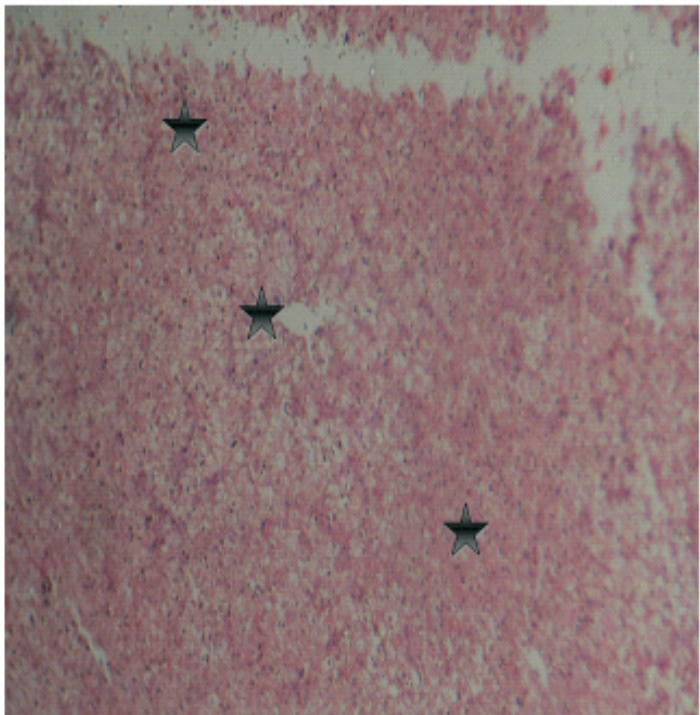

PLate:1b.Photomicrograph of the transrerse section of the liwer of Claries geriepinus fed Hibiscus vabdariffa meal (HSMA) diet. Stars show Liver large loci of hepatic vacuolation degeneration. H \& E. X 100.

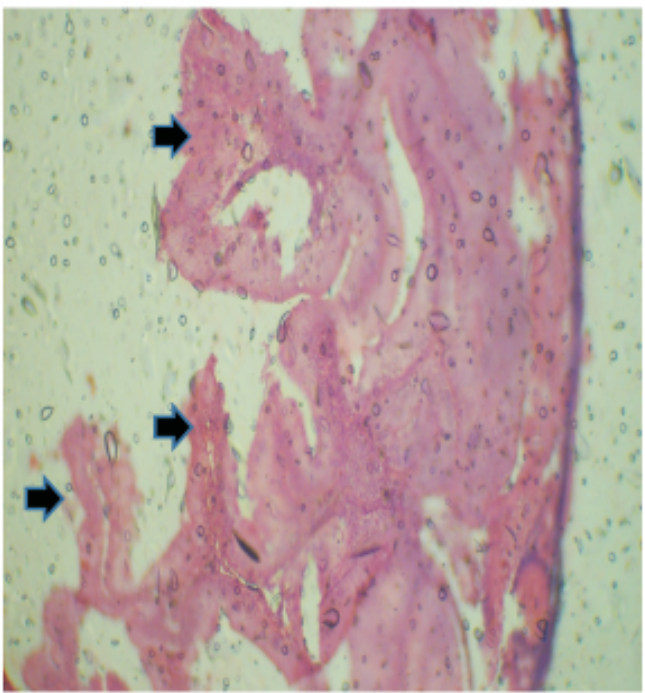

Plate $2 \mathrm{~b}$-Photomicrograph of the transverse section of the stomach/ intestine of Clarias gariegimas fed HSM4 diet. Arrons show slightly shortened gastric villi. H \& EX 100 .

non-specific responses in fish which enable the fish to cope with the disturbance and maintenance of its homeostatic state. If severe or long lasting, the response than becomes mal-adaptive and threatens the fish health and wellbeing/death (Omotosho, 2017). The assumption that is generally made with these indices is that lower than 


\section{Adewole}

normal values indicates a diversion of energy away from organ or tissue to combat stressor (Barton, 2002). Exposures of the fish to the graded levels of HSM's diets produce a significant decrease in the CSI when compared with the control. The result obtained in the present study differed from the reported non-significant effect of administration of aqueous and ethanolic extracts of $H$. sabdariffa in albino rats. The disparities obtained may be due to the species of animal models, concentrations of the extracts used, the method of extraction /solvent used, method of administration and the varieties of $H$. sabdariffa used in other studies (Ojokoh, 2006; Adewole, 2014). Furthermore, the results obtained in this study showed that there were significant differences $(p<0.05)$ in most of the organosomatic indices measured except the VSI that was non -significantly different ( $p>0.05)$. This is contrary to the summations of Ebenebe et. al. (2018) and Esiegwu et. al. (2013) that reported that there were no treatment effects on the weight of the liver, lungs, and hearts of rabbits fed with Garcinia kola seed meal. However, Ebenebe et al. (2018), observed that there were significant differences $(p<0.05)$ in the carcass and kidney weight of rabbits, but these indices followed no specific pattern that could be attributed to the effect of the bitter kola. HSI is one of the most investigated biomarker due to important role of liver in detoxification of pollutants. While Dogan and Can (2011) observed that organosomatic index is an appropriate bioindicator for endocrine disruption in fish consequent of chemical exposure. The results of this study showed that, a statistically significant difference $(\mathrm{p}<0.05)$ was noted in the HSI, but did not follow a definite pattern and less consistent. The decreased in the weight of liver suggests a decrease in the production of endoplasmic reticulum for protein synthesis in liver tissue under toxicant exposure (Bennet and Wolke, 2004). Liver weight reduction could also be as a result of decreased lipid storage (Gabriel et al., 2010). Similar slight decrease in weight of liver was observed as the concentration of cypemethrin increased to $0.25 \mathrm{~m} / \mathrm{L}$ ${ }^{1}$ (Ariweriokuma et al., 2011). The liver enlargement (raised HSI) observed in some diets of HSMs can be associated with increased detoxification enzyme activity, and this was similarly reported by Gabriel et al. (2010) in catfish hybrid exposed to bleached kraft mill effluents. Also, Katalary and Pariak (2004) observed that acute toxicity varies widely among fish species, depending on the concentrations of chemical, age of fish and exposure period.

Acute and sub-acute toxicity profiles of different extracts of parts of $H$. sabdariffa have been reported widely in literature (Ali et al., 2005) with conflicting reports. Therefore, the histopathological examinations of the organs of C.gariepinus particularly of the liver revealed a gradual changes from mild to moderate and severe diffused hepatic vacuolar degenerations as the concentrations of $H$. sabdariffa meal diets increased (>HSM4 diet). The liver of fish fed HSM4 meal diet which had the highest growth (data not shown) (Adewole, 2014) revealed that the liver demonstrated mild diffuse hepatic vacuolar degeneration and the intestine showed mild stunted gastric villi. The observed changes in the liver of $C$. gariepinus fed $H$. sabdariffa are similar to the reported alterations in the liver morphology of rat fed calyx diet (calyx and fermented with wood ash) by Ojokoh (2006). The results suggested that Roselle calyx may cause fatty infiltration which could possibly lead to liver damage, if not properly detoxified. Similarly, the intestinal histopathology showed some level of atrophy suggesting indigestibility. This could be attributed to the presence of 


\section{Organosomatic indices and histopathological response of Clarias gariepinus}

tannins, which has been described as phenolic compounds whose degree of hydroxylation and molecular size are sufficient to form complexes with protein in the calyces of $H$. sabdariffa (Goldstein and Swain,1963) and cyanogenic glucosides has been reported to be an inhibitor of several enzyme catalyzed processes (Aletor,1993).

The interest in the use of functional food as dietary supplements/additives in nutritional studies can make positive alterations, as it has immense health benefits (Ajibola, 2015; Steinberg et. al., 1996). However, the medicinal values of $H$. sabdariffa have captured research interest recently, but, some of its anti-nutritional properties may cause some histopathological alterations. This observation from this study is similar to findings of (Braide, 1990; Braide and Grill, 1990, Esiegwu et. al., 2013 and Ebenebe et. al., 2018) that dried powdered of $G$. kola seed meals fed to rat, laying hens and rabbits caused some alterations in their livers and kidneys, respectively.

\section{Conclusion}

Despite the improved growth performance of $H$. sabdariffa in diet of C.gariepinus, this study revealed the usefulness of monitoring the effect of different types of fish feed (quantitatively and qualitatively) in order to determine positive and/or/negative impacts' on the morphological changes of fish organs. This is very essential in the assessment of the suitability of new or novel feed/chemical substances in fish production and in the quest to finding an alternative to synthetics drugs in fish health management. It recommended that its consumptions must be done with caution to avoid deleterious effects on the organs, while, large doses especially for longer durations should be avoided. Also, that further processing of the calyx may reduce the toxicological effects of the various phytochemical components found in Hibiscus sabdariffa.

\section{References}

Adewole, A. M. 2014. Effects of Roselle as dietary additives on growth performance and production economy of Clarias gariepinus. Journal of Emerging Trends in Engineering and Applied Sciences (JETEAS). 5 (7): 1-8.

Ajibola, A. and Erlwanger. K. H. 2017. Functional food promotes digestive functions and health growth of animals nurtured in confinement. Nigerian Journal of Animal Production, 44:76-88.

Alector, V. A. 1993. Allelochemicals in plant food and feedings stuffs: 1 . Nutritional biochemical and physio-pathological aspects in animal production. Veterinary and Human Toxicology 3: 57-67.

Alector, V. A. and Osho, I. B. 2009. Formulation of medicinal plants for animal production. Invited paper II. Proceedings of the Humboldt Kellog/5th Annual Agric. Conference on formulation of medicinal plants for crop and animal production in Nigeria: Realities and Challenges. 21st 23rd April, 2009. Federal University of Technology Akure. Pp 7-18.

Ali, B. H., Wabel, N. A., Blunden G. 2005. Phytochemical, Pharmacological and toxicological aspect of Hibiscus sabdariffa L., A Review. Phytother.Res. 19:369-375.

Ariweriokuma, S. V., Akinrotimi, O. A., and Gabriel, U. U. 2011. Effects of cypermethrin on condition factor and organosomatic indices of Clarias gariepinus; Journal of Agriculture and Social Research (JASR) Vol. 11, No. 2 pp 67-72. 


\section{Adewole}

Atal, C. K. and B. M. Kapur, 1987. Cultivation and utilization of medicines plants. Jammu-tawi: Regional Research Laboratory $\mathrm{p}$. 115-18.

Barton, A. B. 2002. Stress in fishes: a diversity of response with particular reference to changes in circulating corticosteroids. Integr. Comp. Biol. 42:517-525.

Bennet, R. O. and Wolke, R. C. 2004. The effects of sub lethal endrin exposure on rainbow trout Salmo gairdner.Journal of Fish Biology 31:375-385.

Braide, V. B. 1990. Pharmacological effects of chronic ingestion of Garcinia kola seed in rats. Phytotherapy Research; 4. (1): 3941.

Braide, V. B. and Grill, V. 1990. Histological alterations by a diet containing seeds of Garcinia kola: effect on liver, kidney intestine in the rat. Gegenbaurs Morphol. Jahrb. 136(1): 95-101.

Dogan, D. and Can. C. 2011. Endocrine disruption and altered biochemical indices in male Oncorhynchus mykiss in response to dimethoate. Pesticide Biochemistry and Physiology, 99: 157-161.

Ebenebe, C. I., Chiedu, C. L., Nwagbata, O. C. and Ogbu, O. C. 2018. Growth performance, organ weight and histology of rabbits fed graded levels of bitter kola (Garcinia kola).Nig. J. Anim. Prod. 45 (1): 198-204.

Esiegwu, A. C., Enyenihi, G. E., Emenalom, O. O., Okoli, I. C. and Udedibie, A. B. I. 2013. Organ reaction of laying hens to dietary intake of Garcinia kola seed meal. Inter. J. Agric. Rural Dev. 16: 1580-1587.
Ezekwesili, C. N., K. A. Obiora and O. P. Ugwu 2004. Evaluation of antidiarrhoeal property of crude aqueous extract of Ocimum gratissimum L. (Labiate) in rats. Biokemistri 16(2). $122-131$.

Gabriel, U. U. Obomanu, F. G., Orlu, E. E. and Oveh, O. D. 2010. Fulton's condition, organ indices and haematological responses of catfish hybrid (Heterobranchus longifilis, 全 Clarias gariepinus ㅇ) to aqueous extracts of leaves of Lepidagathis alopecuroides. Ethiopian Journal of Environmental Studies and Management. Vol. 3, No1. Pp. 3034.

Goldstein, L. and T. Swain. 1963. Change of ripening fruits. Phytochemical, 2:271-283.

Guillo, R. T. and Hinton, D. E. 2008. The toxicology of fishes, CRC Press, Taylor and Francis Group Boca Raton $1071 \mathrm{pp}$.

Hu, X., Sato, J., Oshida, Y., Yu, M., Bajotto, G. and Sato, Y. 2003. Effect of Goshajinki-gan (Chinese herbal medicine): (Niu-che - senqi-wan) on insulin resistance on streptozotocin induced diabetic rats. Diab. Res. Clin. Pract. 59:103-111.

Katalary, S. and Pariak, P. 2004. The effect of pollution on haematological parameter of black guby (Gobius) in Foca and Aliaga Bays. J. Fish and Aquat Sci. (2):113-117.

Maxwell, L. B. and Dutta, H. M. 2005. Diacinon induced endocrine disruption in sole gill sun fish Lepomis macrochirus. Ecotoxicology and Environmental Safety 60:21-27. 
Ojokoh A. O., F. C. Adetuyi, F. O. Akinyoboye and V. O. Oyetayo 2002. Fermentation studies on Roselle (Hibiscus sabdariffa) calyx neutralized with trona. $J$. Food Tech. Afr. 7:75-76.

Ojokoh A. O., 2006. Roselle (Hibiscus sabdariffa) calyx diet and histopathological changes in liver of Albino rats. Pakistan Journal of Nutrition 5(2): 110-113.

Omotosho, J. S. 2017. "Fish: their prize and pain" $174^{\text {th }}$ Inaugural Lecture, University of Ilorin, Ilorin, p8.
Robert, R. J. 1978. The anatomy and physiology of teleost. In: Robert, R.J. Ed: In Fish Pathology, pp.13103. Bailliere, Tindall, London.

Steinberg, D., Kaine, G. and Gedalia, I. 1996. Antibacterial effects of propolis and honey on oral bacteria. Am. J. Dentistry, 9: 236239.

Wang, C. J., Wang, J. M., Chon, F. P. and Tseng, T. H. 2000. Protective effect of Hibiscus anthocyanin's against tert-butyehydroperoxide induced hepatic toxicity in rats. Food Chemistry and Toxicology, $38: 41$.

Received: $18^{\text {th }}$ August, 2018

Accepted: $21^{\text {st }}$ December, 2018 